\title{
Quinoa Expansion in Peruvian Departments and Land Use Change before the Health Crisis
}

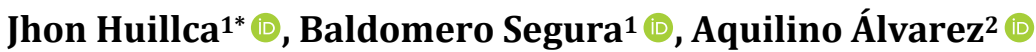 \\ ${ }^{1}$ Department of Economics and Social Sciences, Universitat Politécnica de Valencia, Valencia, Spain \\ ${ }^{2}$ Centro de Investigación en Cultivos Andinos (CICA), Universidad Nacional de San Antonio Abad de Cusco, San Jerónimo, \\ Cusco, Perú \\ Email: ^reydejon_2007@hotmail.com
}

How to cite this paper: Huillca, J., Segura, B. and Álvarez, A. (2021) Quinoa Expansion in Peruvian Departments and Land Use Change before the Health Crisis. Agricultural Sciences, 12, 827-843. https://doi.org/10.4236/as.2021.128053

Received: July 5, 2021

Accepted: August 3, 2021

Published: August 6, 2021

Copyright () 2021 by author(s) and Scientific Research Publishing Inc. This work is licensed under the Creative Commons Attribution International License (CC BY 4.0).

http://creativecommons.org/licenses/by/4.0/

\begin{abstract}
National and international policies have promoted quinoa consumption, influencing the expansion of the crop, and generating changes in land use. In this article, we analyzed the evolution of quinoa cultivation in Peru both at the national and departmental levels. Time series analysis vas used to. Between 1951 and 2019, the evolution of the quinoa-harvested areas in Peru has gone through various stages, first in regression until 1990, and then it has experienced a growth rate of $10 \%$. Puno is still by far the department where the crop is most widespread. Taking into account the geographical and technological conditions, this highland area is less likely to maintain the rate of expansion than the Peruvian coast, which will imply great challenges for Andean farmers who have maintained the traditional crop throughout the period.
\end{abstract}

\section{Keywords}

Quinoa, Land Use, Expansion Rate, Time Series, Traditional Zones

\section{Introduction}

Quinoa (Chenopodium quinoa W.) is a plant native to the Altiplano, located between the present-day countries of Peru and Bolivia, which was domesticated by ancient pre-Inca civilizations (Quechua and Aymara) and selected for cultivation during the Inca period (c.1400-1533). Quinoa has been cultivated for 7.000 years throughout the Andean region of South America and has become one of the main foods of the Andean people [1] [2], mainly due to its high adaptability, which has allowed it to be cultivated in different agro-ecological zones, consolidating its social, economic, and environmental importance [3] [4].

Before colonial times, quinoa was the second most important crop after the 
potato. Due to the large quantities of the crop that the Spanish found in 1532, together with large quantities of other grains in food deposits (qolqas in Quechua), and because of its size, they called it millet or small rice [5]. In addition to the use of grain and tender leaves in human and animal food, it was also used in religious ceremonies to make offerings to their gods, that for an along with other Andean grains, was losing importance to other non-native species (wheat, barley, carrot, and broad bean) which became established as alternative foods. More recently in the 1960s, as a result of the migratory processes derived from the prevailing industrial development model and the effects of the Green Revolution, some ancestral cultivation technologies that had kept Andean crops in balance were modified, reducing indigenous grain production even further [6] [7]. These techniques were applied more extensively on the flat areas of the coast than in the Peruvian highlands.

Nevertheless, quinoa cultivation was maintained in higher areas, under traditional production systems, mainly linked to small-scale family farming, with areas of less than five hectares [8]. These smallholdings have garnered little attention, and in many cases have been neglected by national and regional governments. It is precisely in these areas where there is the greatest concentration of cultivated and wild quinoa diversity, under traditional production, and in harmony with the natural environment [9] [10] [11]. These traditional farming systems have thus managed to maintain a wide genetic variability, which gives them a certain competitive advantage over other regions and countries in the world. What is particularly significant for quinoa cultivation around the Peruvian Altiplano, which despite its intensification and standardised specialisation for commercial purposes, is the significant reduction in number of local varieties [12] [13]. In the Peruvian Andes, there has been greater resistance to displacement by improved varieties than in the inter-Andean valleys and on the coast. Large areas in the mountainous Sierra boast greater genetic variability, but with lower yields, especially in areas of higher altitude, is the case in Puno and Ayacucho [8] [14].

Traditionally, quinoa production in South America has been mostly localised in Peru and Bolivia, although it has also been present in the rest of the Andean countries. This expansion of the crop has not only been limited to the South American continent, because it has also spread to the rest of the world. In 1900 it was cultivated only in six countries, but throughout the last century, it has been introduced in Africa, North America, Europe, and Asia, reaching a total of 123 countries at present [15] [16].

This global expansion logically causes an increase in supply, with the consequent adjustment in international prices, once again conditioning the response in the traditional production areas. Peru remains the world's leading producer and exporter for the sixth consecutive year [15] [17] [18], maintaining its advantage over the rest of the world, and influencing the price of the grain both in the domestic market and globally. 
Within the Peruvian context, it had traditionally been cultivated in 13 departments, with around $95 \%$ of the surface area concentrated in the Sierra [8] [16]. The high adaptability of the crop and the increase in national and international demand has allowed for this expansion, facilitating a staggered introduction to new areas. Between 2009 and 2014, its cultivation increased from 13 departments to 19 of the 24 comprising the country [14] [17].

Between 1995 and 2014 the average rate of expansion of the Peruvian quinoa area observed (16\%) was higher than the expected rate $(3 \%)$, thanks to the boom in demand for the grain [8]. During this period, the areas which had previously been cultivated in the 1950 decade were restored to their former levels of production, and new quinoa geography emerged [19]. Interestingly, in departments where quinoa was a traditional crop, there were very high growth rates, with Arequipa standing out with a rate of $140 \%$, followed by Ancash (108\%), La Libertad (59\%), Junín (46\%), Huánuco (42\%), Ayacucho (39\%), Cajamarca (18\%), Apurímac (17\%), Huancavelica (13\%), Cusco (6\%), and Puno (4\%) [8]. However, in the last five years, this rate of expansion has slowed considerably, probably due to the impact of lower prices caused by the increase in world supply.

Traditional departments form the basis of national production, supporting both self-consumption and the national market within the country, while production in non-traditional departments contributes more volume destined for exports. However, the instability of production in the new geographical areas does not guarantee a set pace of growth, nor the conservation of the harvested area, thus generating a scenario of uncertainty regarding the future. For these reasons, analyzing the evolution of new areas harvested with quinoa will inform us in such a way that management measures can then be proposed to sustain the recovered land, and consequently the supply of the grain to national and international markets.

In this study, we analyzed the territorial expansion of quinoa cultivation in Peru, both at the national and departmental levels. First, we have analyzed the evolution of the harvested area between 1950 and 2019 and its relationship with the different national and international policies developed in each period. Secondly, we have compared the evolution of the area cultivated in the departments, distinguishing between traditional and non-traditional, presenting a cartographic mapping of the quinoa-producing departments according to a range of surface areas.

\section{Materials and Methods}

\subsection{Data}

Data on quinoa-harvested areas corresponding to the period 1951-1966 were obtained and estimated from Tapia et al., while for the period 1967-2019 data were obtained from Serie Estadística de Producción Agrícola (SEPA) of the Peruvian Ministry of Agriculture and Irrigation (MINAGRI) [20]. This also pro- 
vided the source of national price data for the years 1991 to 2019. International price data from 1990 to 2019 were obtained from Trade Map of International Trade Center (ITC) [21]. These data have been collected separately for all quinoa-producing departments or regions. Traditional departments have been considered as those with a continuous record throughout the time series, including Puno, Ayacucho, Apurímac, Cusco, Junín, Huancavelica, La Libertad, Arequipa, Cajamarca, Huánuco, Ancash, Moquegua, and Amazonas. Departments introduced since 2010 have been considered as non-traditional and include Ica, Tacna, Lima, Lambayeque, Pasco, and Piura.

\subsection{Data Analysis}

Firstly, we carried out an analysis of the annual series of cultivated areas at the national level between 1951 and 2019, with the aim of understanding their evolution and obtaining a model that allows us to describe changes during this period. This was done regarding the national and international price, identifying some possible causes to the curve and allowing for us to make forecasts about the immediate future.

Secondly, we drew a comparison of harvested areas between departments where quinoa has been cultivated between 1967 and 2019, using descriptive statistical methods as [19] [22] [23], in order to analyze the variations in the growth of the relevant area in producing departments. For this purpose, we have considered 13 traditional and 6 non-traditional departments. This was followed by a comparison of averages of the most important traditional departments, with the aim of finding out significant differences in surface areas. In a complementary manner, an analysis of growth rates was carried out, taking 1967 as the base year to ascertain and compare the rate of expansion, and the proportion of surface area they contribute to the national area, which indicates the level of importance of the land occupied by quinoa.

Finally, the weight of the cultivated area of quinoa-producing departments was plotted using ArcGIS version 10.3 on data from extreme scenarios compiled by MINAGRI [20]. The cartographic mapping has been carried out on a national scale, on a political map of Peru divided by its departments, differentiated by colour relating to surface area ranges. This has been done in a manner similar to those applied by [8] and [15] and allows a comparative visualization of productive areas between the period of underutilization and the quinoa boom in the departments of Peru.

\section{Results and Discussions}

\subsection{Analysis of the Evolution of the Area under Quinoa Cultivation in Peru}

The evolution of the quinoa-harvested areas in Peru has gone through various stages. As can be seen in Figure 1, the level of the annual series shows a variation, with the trend curve changing between negative, constant, and positive. 


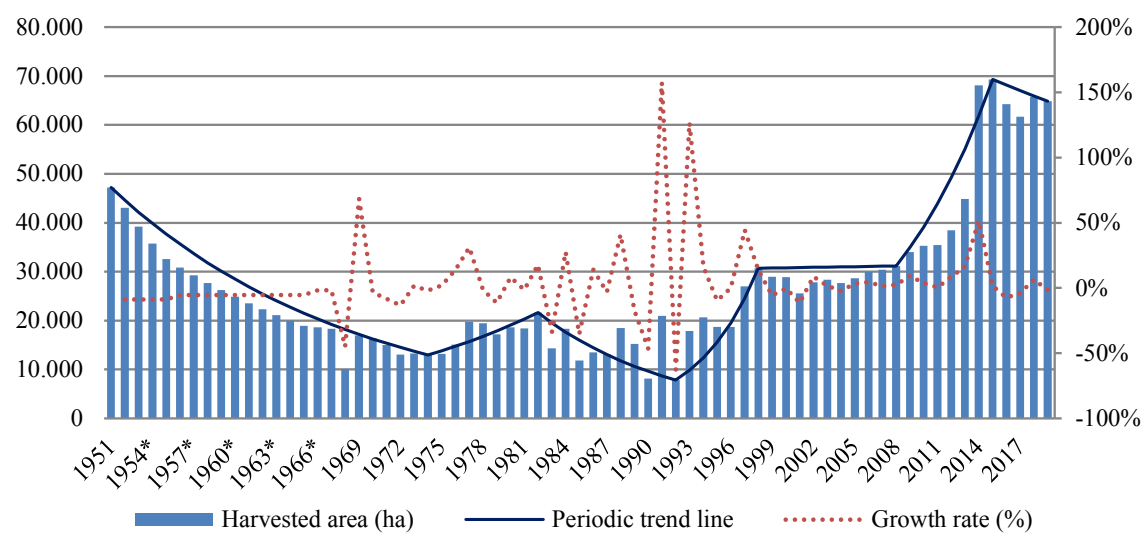

Figure 1. Evolution of quinoa harvested area in Peru between 1951 and 2019.

This means that there are different growth rates, which led us to establish several periods. In the first period (1951-1974), the level of the series shows a clearly decreasing trend at an almost constant rate of $-5 \%$, going from 47.200 to 12.980 hectares, meaning a $75 \%$ reduction in the area cultivated with grain.

This period coincides with the application of principles of the development aid programs of the time. These were based on the successes of the so-called Green Revolution, which imposed a displacement of traditional crops and technologies, with higher productive yields [12] [24]. It also coincides with the period of migration to city capitals in the early 1960 decade [25] and also with the Peruvian Agrarian Reform of 1969, which led to an increase in land area through the recovery and direct administration of land by the farmers themselves [26] but seemingly did not favour the recovery of traditional crops. We can also observe a second period between 1974 and 1982 in which there was a slight recovery, at a rate of $7 \%$, which coincided with attempts to add value to Andean grains through their industrialisation and marketing [27]. But low demand for these products ended up affecting profitability and sustainability, failing to displace that from other cereals.

In the following decade (1982-1992), the series returned to an overall negative trend, very irregularly, at a rate of $-10 \%$, with only 7.874 hectares, being cultivated in 1992, the smallest area that Peru had in its known history, therefore constituting the longest period of underutilisation of the crop. This situation was due on the one hand to the rise of other introduced grains with higher yields, which have occupied the plots traditionally dedicated to quinoa. On the other hand, the contemptuous consideration of the grain as food for indigenous and poor people [12] [18] have reduced the areas under cultivation.

During the following decade (1992-1998) the level of the series changed again, showing an upward trend at a high rate (25\%), reaching 30.720 hectares, driven by the change in policies of the Peruvian State from a closed to an open economy, a neoliberal model [27] [28] [29] that promoted the initiation of regional trade agreements and free trade agreements. This put non-traditional export produce on the world stage, including quinoa as an agro-industrial raw material 
[21] [30]. Quinoa was also included in development projects for Andean grains, and together with other grains (kiwicha, barley, rice, soya, among others) it was considered in the social program Vaso de Leche ("glass of milk"), with national rollout [31]. The FAO included it through the "American and European Test of Quinoa" project (1996-1998), which was the first mechanism for international dissemination [32], which contributed to the recovery of surface area, this being the first impulse towards the expansion of the crop In the first decade of this century (1998-2008), the level of cultivation remained practically consistent with the level reached at the end of the previous period, due to the lack of attention to the development of Andean grain projects as well as low grain prices. From then until 2015, a phase of unprecedented growth began, with 69.305 hectares, being cultivated, far exceeding the area at the beginning of the 1950s and reaching its highest level in history.

This expansion was due both to national policies through the direct purchase of grain for the Qaliwarma social program, and soup kitchens [23]. In addition to the international policies of the FAO, following the designation of 2013 is as the International Year of Quinoa. Furthermore, recognition of the indigenous Andean peoples' efforts in maintaining this millenary grain of high nutritional value was a contributing factor. The International Year of Family Farming in 2014 influenced because near of $97 \%$ of quinoa producers are family farmers [33] [34], also had contributed to the expansion of the crop, which was recognized to be in harmony with the environment.

Finally, in the last six years, a slight contraction of the cultivated area has been observed, as a response to the drop in export and producer prices since 2014 (Figure 2) caused by the change in global supply. Although grain prices between 2016 and 2019 have been reduced by 50\% compared to 2014, being like the prices paid before the quinoa boom (2008-2012), it is still much higher than the 1990s. However, the slight recovery of the 2019 price has encouraged the recovery of the cultivated area, making it stay above 65.000 hectares and being an area almost double what had been cultivated at the end of the decade 1950, which is a significant increase and prolonging the quinoa boom.

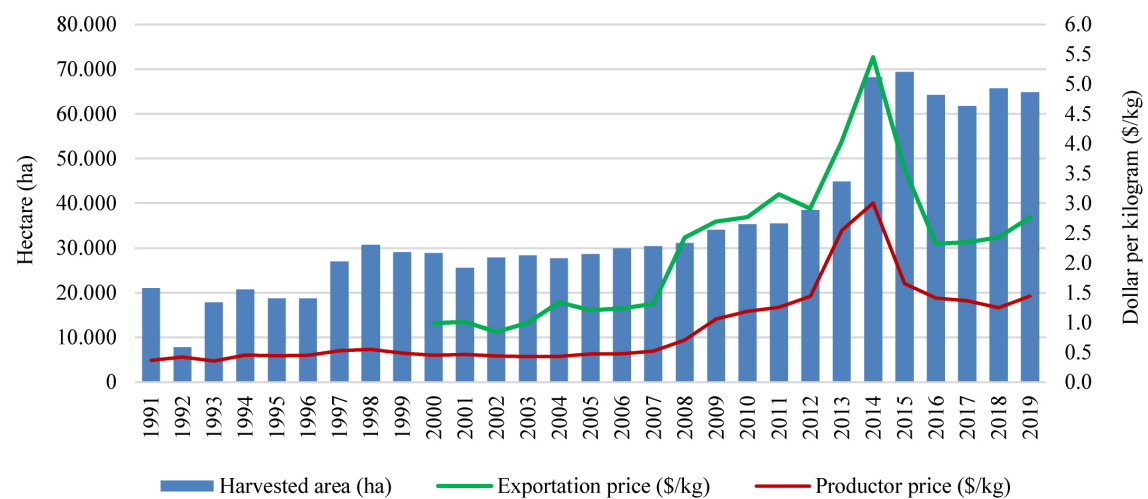

Figure 2. Harvested area and marketing prices behaviour 
The harvested area series does not present a stationary behaviour, neither in mean nor dispersion. In fact, the best model obtained with the Statgraphics XVII program for the untransformed data based on the Akaike information criterion is a random walk without drift. The different predictive models analysed provide a high variability of the area cultivated with quinoa in the Peruvian territory, although most of them predict maintenance of growth. The ARIMA $(1,2,2)$ model is the only one that satisfies all the white noise tests on the residuals whose parameters we have reflected in Table 1.

The analysis of this series allows us to observe in Figure 3, two phenomena: firstly, there is a continuous decrease in land used for quinoa production until 1992, which implies a change in the use of land that was displaced by other exotic species on the rise; secondly, there was a permanent recovery of the areas that had previously been lost and since 2014 quinoa production has been booming.

As can be seen in Figure 3, the forecast is to maintain growth, but the impact that technical and economic effects could have in the coming years must be considered. This includes factors such as the standardization and intensification of cultivation, affecting land fertility, the management of varietal purity, and the loss of biodiversity due to displacement using improved varieties. Allegedly, this could cause a multidimensional disaster [6] [13] [35]. All told, this poses great challenges for farmers in traditional areas, due to the technological, geographical,

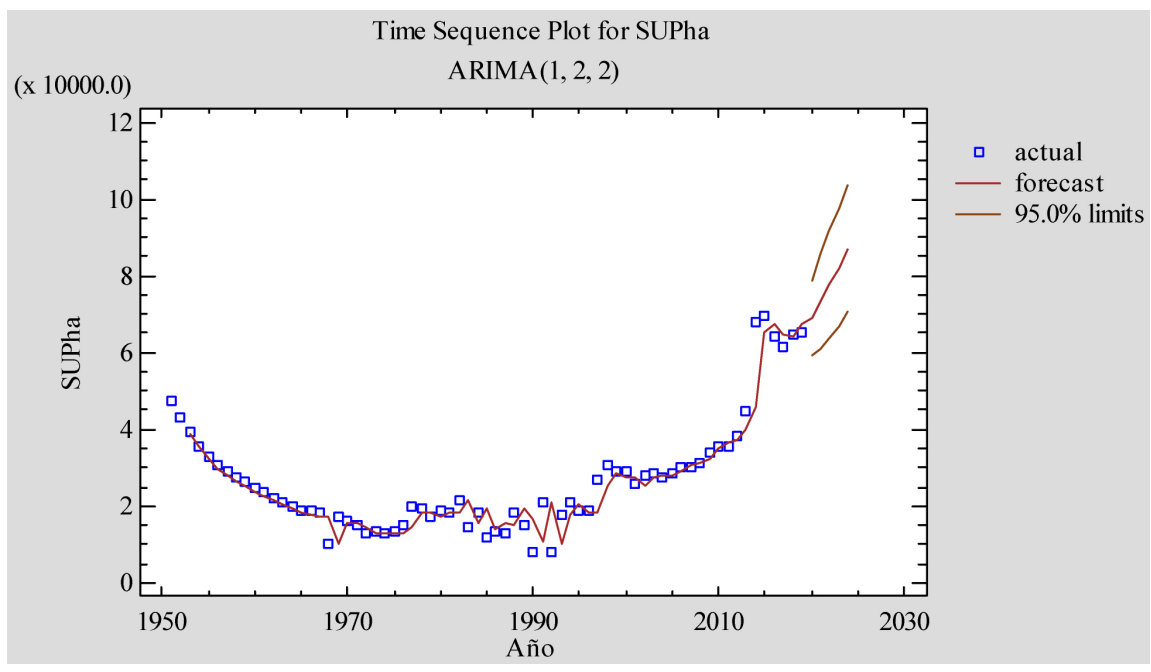

Figure 3. Time sequence forecast for harvested area in the Peruvian territory.

Table 1. Summary of the ARIMA Model to harvested area.

\begin{tabular}{|c|c|c|c|c|}
\hline Parameter & Estimated & Standard error & $\mathrm{t}$ & $\mathrm{P}$-value \\
\hline $\operatorname{AR}(1)$ & 0.798581 & 0.0463091 & 17.2446 & 0.000 \\
\hline MA (1) & 1.97525 & 0.00726258 & 271.977 & 0.000 \\
\hline MA (2) & -1.00211 & 0.010447 & -95.9235 & 0.000 \\
\hline
\end{tabular}


and climatic conditions under which they operate. They are already at a disadvantage when compared to larger-scale producers. In the national context, geographical limits must also be considered, as the Sierra does not give the option to increase into the cultivated flat areas, while the coast has a higher yield and moreover, the potential to increase the area. In an unfavourable scenario, production in the Sierra would be reduced to a far greater extent than at the coast.

\subsection{Descriptive Comparison of Departmental Quinoa Surface Area}

The existence of 13 traditional quinoa-producing departments has been determined for the period 1967-2019, distributed in various geographical areas among the Peruvian Sierra and coast. Table 2 shows a descriptive comparison of the harvested areas, according to the order of importance. Puno leads, with an average of 18.126 hectares, with a concentration of more than $65 \%$ of the national area historically, although the variability observed in the said period is high; with a coefficient of variation of $47 \%$, it is considerably lower than that observed in the rest of the traditional cultivation departments. The latter have less quantitative importance but greater variability in area. Ayacucho and Junín with averages of 2.041 and 1.434 hectares are in second and third place respectively, while the rest have average areas of less than 1.000 hectares.

It is worth noting that Arequipa, with 252\%, has presented a higher coefficient of variation than the rest of the departments, due to the expansion of the crop to the flatter areas at the coast, while Ayacucho and Apurímac fall in second and third position, showing the greatest variability within the Sierra. However, geographical conditions and other factors of the Andes limit the expansive capacity, thus demonstrating that the Peruvian Sierra has less potential to continue the expansion rate than the coast.

Table 3 shows a descriptive comparison of the harvested area between non-traditional departments, Tacna and Lambayeque leading the average harvested area. Ica had a higher coefficient of variation, indicating greater area variability and therefore greater expansion. The rest of the non-traditional departments (Piura, Lima, and Pasco) have merely a token production. All of them

Table 2. Descriptive comparison of harvested area between traditional quinoa departments.

\begin{tabular}{|c|c|c|c|c|c|c|c|c|c|}
\hline Traditional department & Puno & Ayacucho & Junín & Cusco & Apurímac & Arequipa & Ancash & Huancavelica & Rest of traditional \\
\hline Count & 53 & 53 & 53 & 53 & 53 & 53 & 53 & 53 & 53 \\
\hline Average & 18.126 & 2.041 & 1.434 & 1.147 & 988 & 553 & 548 & 504 & 998 \\
\hline Standard deviation & 8.485 & 3.461 & 1.029 & 980 & 1.130 & 1.392 & 477 & 424 & 939 \\
\hline Coeff. of variation & $47 \%$ & $170 \%$ & $72 \%$ & $85 \%$ & $114 \%$ & $252 \%$ & $87 \%$ & $84 \%$ & $94 \%$ \\
\hline Minimum & 4.395 & 105 & 500 & 135 & 190 & 50 & 12 & 81 & 215 \\
\hline Maximum & 36.092 & 13.766 & 5.281 & 3.326 & 5.080 & 8.109 & 1.690 & 2.312 & 4.021 \\
\hline Range & 31.697 & 13.661 & 4.781 & 3.191 & 4.890 & 8.059 & 1.568 & 2.231 & 3.806 \\
\hline
\end{tabular}


Table 3. Descriptive comparison of harvested area of non-traditional departments.

\begin{tabular}{ccccc}
\hline Non traditional department & Tacna & Lambayeque & Ica & Rest non traditional \\
\hline Count & 9 & 7 & 12 & 38 \\
Average & 361 & 290 & 102 & 40 \\
Standard deviation & 328 & 451 & 166 & 134 \\
Coeff. of variation & $91 \%$ & $156 \%$ & $162 \%$ & $336 \%$ \\
Minimum & 42 & 3 & 0 & 2 \\
Maximum & 1.140 & 1.268 & 478 & 725 \\
Range & 1.098 & 1.265 & 478 & 723 \\
\hline
\end{tabular}

together, totaling an average of 899.53 hectares, represent only $3 \%$ of the national harvest. However, it is also shown that the coastal departments have greater variability than those of the highlands. It should be noted that non-traditional production areas do not show a significant production, contributing only $3 \%$ of the national surface area. Today, 3 of the 6 non-traditional departments are still in operation, while the traditional departments have represented $97 \%$ of national harvested area.

\subsection{Comparison of Means of Departmental Quinoa Area}

The portion of traditional departments over the total surface area of the country has varied between $47 \%$ and $252 \%$, corresponding with Puno and Arequipa respectively. Furthermore, Puno has the highest minima and maxima data of all departments, and if we analyze its variability among the traditional departments for the period 1967-2019, it appears as the only one statistically different and much higher than the rest, at $95 \%$ confidence (Figure 4). Regarding the rest of the departments, no differences in area cultivated in the period are observed, although it seems that the group formed by Ayacucho, Junín, Cusco, and Apurímac are statistically equal to those of Arequipa, Ancash, and Huancavelica. There is the last group as the rest of the traditional ones (Cajamarca, Huánuco, La Libertad, Moquegua, and Amazonas) that shows a smaller surface than the rest, consequently having less importance upon the national supply of grain. The comparison of averages for the non-traditional quinoa-producing departments has not been possible. The recent and gradual inclusion of the crop in these new geographical areas conditions their analyses due to the lack of uniformity and insufficiency of data, and the low proportional representation on the national scale. However, they could even have a higher growth rate than the traditional departments, so we will now compare their growth against the proportion they represent in the national quinoa surface area.

\subsection{Expansion Analysis and Surface Representation}

In 2019 , the national area reached 65,280 ha, having grown by $257 \%$, when compared to 1967 at the then annual rate of $2 \%$. Among the traditional departments, 


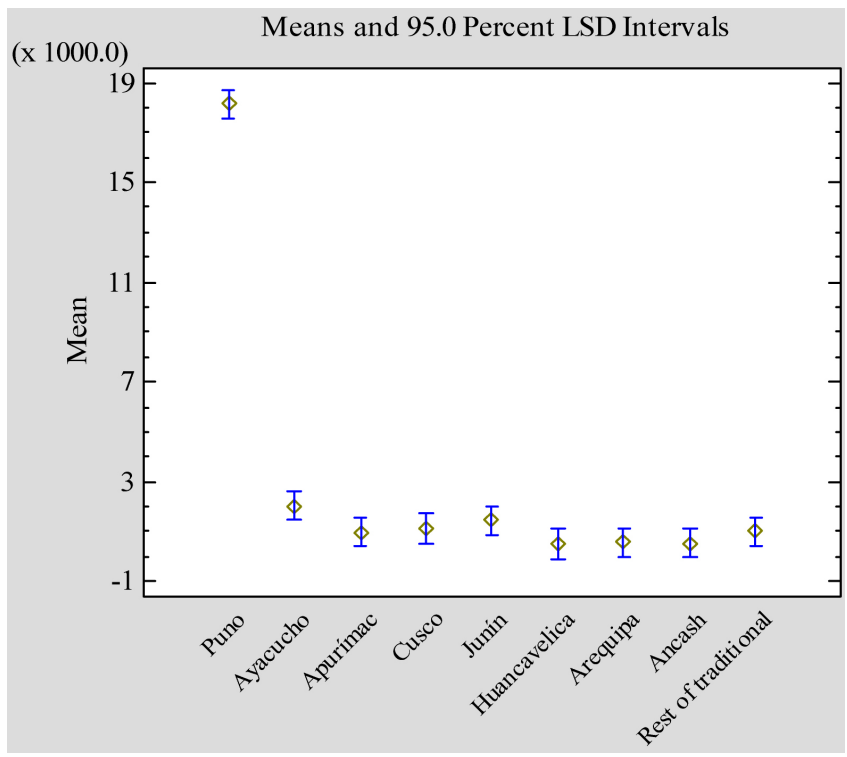

Figure 4. Comparison of means of harvested area of traditional quinoa departments (1967-2019).

Ayacucho with a rate of $7 \%$ showed the highest rate of expansion, followed by La Libertad with 6\%, while Apurímac, Cusco, and Arequipa all had a rate of 5\%. Cajamarca, Huancavelica, and Huánuco had a rate of $4 \%$ and the rest made up of Junín, Moquegua, and Puno had a lower rate than the rest. Ancash and Amazonas showed negative rates. This rate of national and departmental expansion was lower than the rate of expansion observed between 1995 and 2014, but higher than those predicted for 2009-2014. Among the non-traditional departments, Tacna and Ica stood out with a growth rate of $23 \%$ and $18 \%$ respectively, the rest displaying negative rates, of which Pasco and Piura stopped producing altogether.

It is worth noting that in the last 10 years (2009-2019), the rate of growth of both national and departmental quinoa area has far exceeded that of previous decades. This has been led by Arequipa (22\%) and Ayacucho (20\%), although lower rates than those experienced between 2009 and 2014 showed greater expansion than the rest. Apurímac (17\%) maintained its pace, while Huancavelica (17\%) has increased its production. Cajamarca (15\%) and La Libertad (11\%) have declined, and the rest showed a rate of less than $10 \%$ which is still considerable (Figure 5).

We can confirm that in the last 53 years, Ayacucho has had the greatest expansion in the area harvested with quinoa, with almost 30 times what it had in the 1950s, followed by Apurímac, Cusco, and Arequipa, which have increased their respective areas by more than 10 times. Cajamarca, Huancavelica, and Huánuco increased by more than 7 times, and Junín and Moquegua tripled. However, Puno, despite showing less growth, has doubled its quinoa cultivation area and continues to be the most important department in terms of grain supply. In terms of proportion, the national average of quinoa cultivation area 


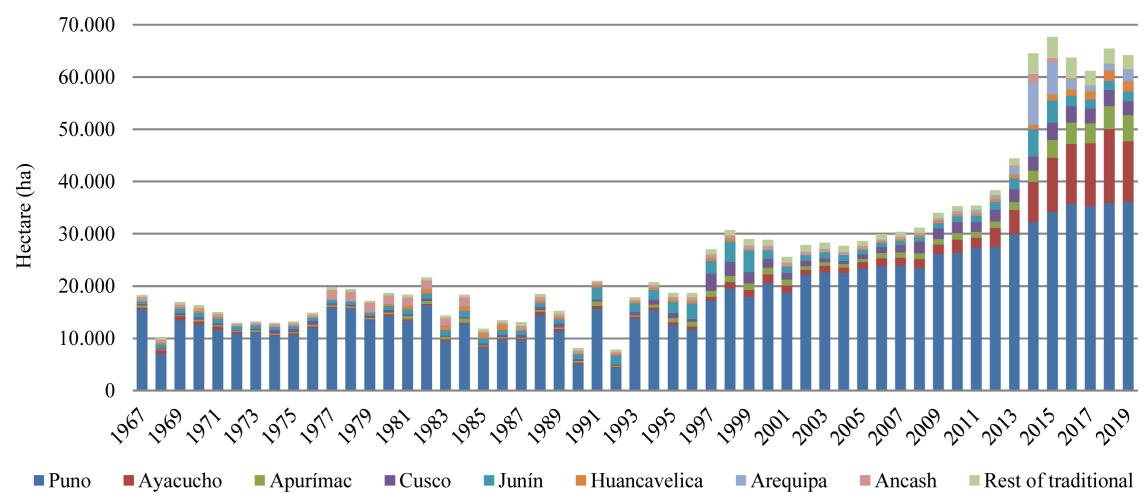

Figure 5. Surface area and participation among traditional departments of quinoa (1967-2019).

between 1967 and 2019 reached 27.217 hectares of which Puno accounted for 67\%, followed by Ayacucho (7\%), Junín (5\%), Apurímac (4\%), and Cusco (4\%). Huancavelica, Arequipa, and Ancash composed far smaller portions, the remaining traditional areas (La Libertad, Cajamarca, and Huánuco) had only a token production (Figure 5), and the non-traditional areas together accounted for barely $3 \%$ of the total.

It is worth noting that in 2015, Peru had the best-harvested area, but this has been difficult to maintain, both nationally and within the departments, with just some exceptions. The effects of crop intensification, normalization, and other factors are causing an alleged social, economic, and environmental disaster [6] [13] [35], which have led to a period of surface area recession between 2016 and 2017. The abandonment of production in the departments of Pasco, Piura, and Amazonas between 2017 and 2019 would have prolonged the period of contraction, but the recovery of national quinoa surface area in the two years since indicates that the exiting of these departments has not affected the period of recession because of their relatively insignificant production levels. Therefore, the recovery of quinoa surface area was due to the productive consistency in traditional departments such as Puno, Ayacucho, Apurímac, Cusco, and Junín, whose location is in the Sierra connects the preservation of ancestral practices to the sustainability of the crop.

\subsection{Cartographic Analysis of Departmental Expansion of Quinoa in Peru}

Since the imminent fall in cultivation that occurred up until the beginning of the 1990s, there has been a notably continuous expansion which we can divide into three periods (1993-2008; 2009-2013; 2013-2019), increasing the rate of around $10 \%$ and the latter period being the highest. Throughout the historical data, two opposing occurrences have been identified which promoted a change in land use and can be visualised through a cartographic analysis. Firstly, a maximum area contraction has been observed, which had occurred up to 1992, the year which indicates the greatest underutilisation of the crop. And secondly, a period of 
maximum expansion occurred in 2015, the year in which quinoa occupied the largest area. Notwithstanding that by 2019 it had been reduced to 16 departments; the national surface area is still booming. Figure 6 shows land contraction for quinoa cultivation being present in 13 of the totals of 24 existing departments. Three different groups have been visualized: the first group made up of the departments of Puno and Junín with a surface area between 1.001 and 5.000 hectares, constituting a larger surface area than the rest; the second, made up of Cusco, Ayacucho, Apurímac, Huancavelica, Arequipa, Ancash, and Huánuco, which cultivated between 101 and 500 hectares; and a third group made up of Cajamarca, Amazonas, La Libertad, and Moquegua with relatively insignificant production using surfaces of less than 100 hectares.

On the other hand, Figure 7 shows the map with maximum expansion of quinoa cultivation, occupying land in 19 of the 24 departments. In this visualization, there is five groups have been specified: a first group made up of Puno and Ayacucho, having the largest areas of quinoa; a second group made up of Apurímac, Cusco, Arequipa, Junín, Huancavelica, La Libertad, and Huánuco, all with surface areas varying between 1.001 and 10.000 hectares; a third group comprising Ancash and Cajamarca with areas ranging between 501 and 1.000

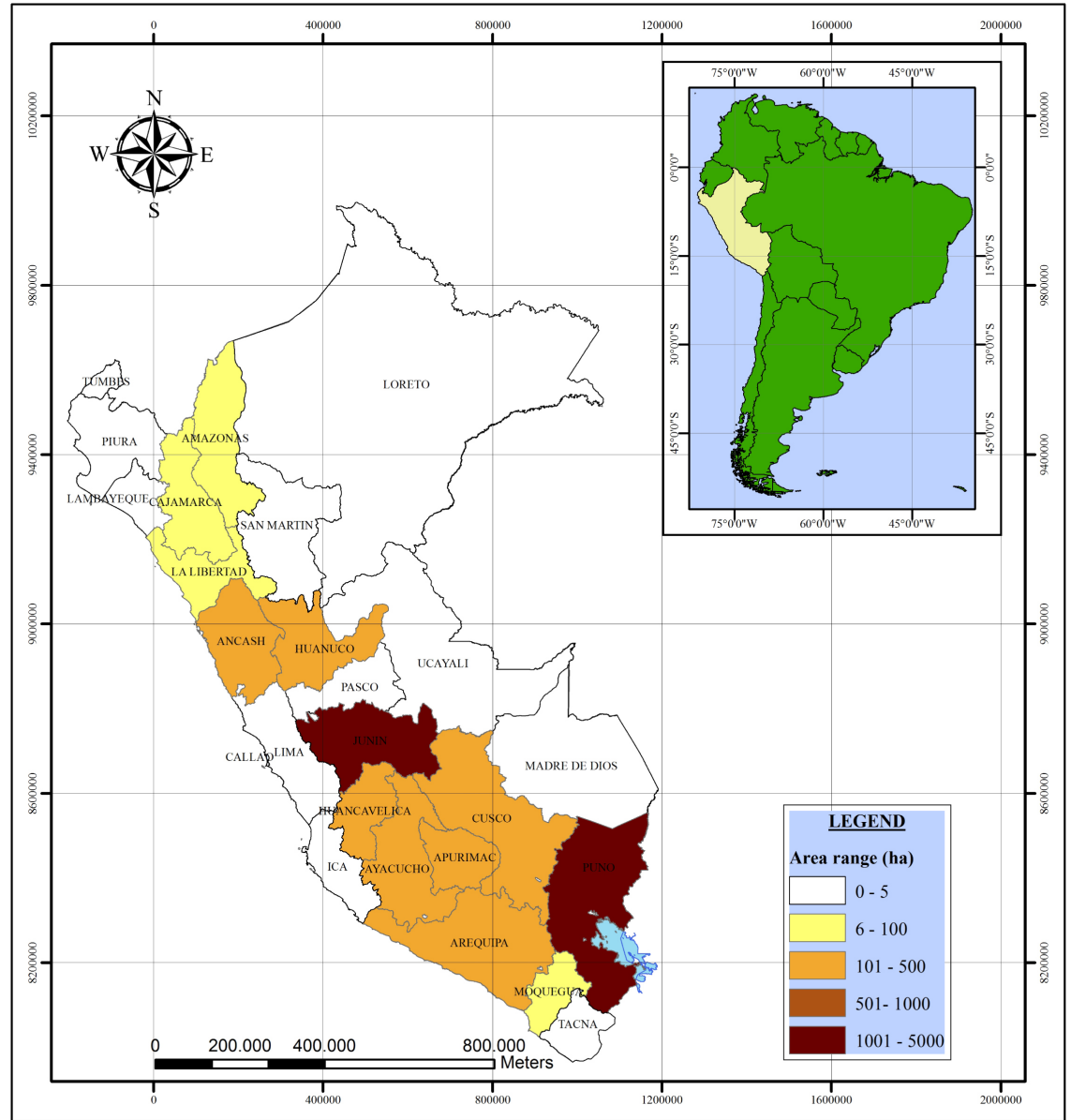

Figure 6. Map of harvested area of quinoa for departments in Perú to 1992. 


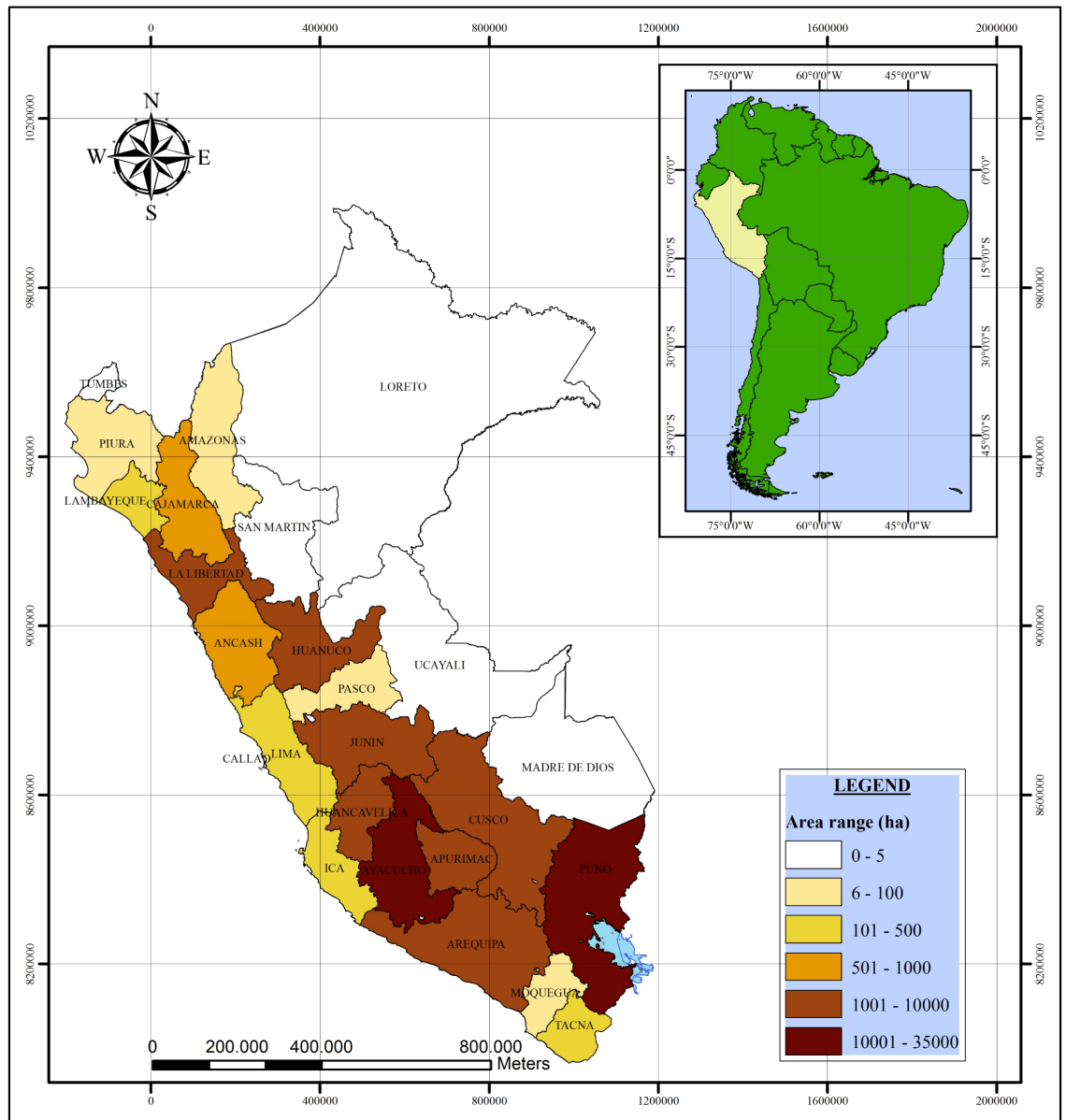

Figure 7. Map of harvested area of quinoa for departments in Perú to 2015.

hectares; a fourth group comprising Ica, Tacna, Lima, and Lambayeque with areas between 101 and 500 hectares, and lastly the fifth group comprising Pasco, Amazonas, Moquegua, and Piura, each with areas of less than 100 hectares, showing merely token levels of production.

Since 1992 there has been a notable change in land use for quinoa cultivation. However, the intensification of cultivation and competition for land caused by the quinoa boom has threatened productive sustainability in the traditional areas, giving rise to the need to propose strategies and instruments to avoid a social, economic, or environmental disaster [6] [35] [36]. The areas that have expanded in the last 10 years have led Peru to position itself as the world's leading producer and exporter of quinoa for the sixth consecutive year. The introduction of new areas has given rise to greater income opportunities and productive diversification, but it has also led to the displacement of native species, even threatening their existence. In traditional areas, local varieties are being replaced by improved seeds, reducing the genetic variability of quinoa [35] [37], and even some ancestral practices are being lost, which had allowed for varietal conservation and enjoyment of the grain for many generations. Therefore, sustainability strategies and policies need to involve public and private institutions with 
agroecological approaches [38] [39]. Their underlying principles must consider sustainability criteria and indicators [40] [41]. These must aim to maintain the area under cultivation, guarantee food security in the context of the health crisis, and supply the grain to the international market, thus improving the income of Andean farmers.

\section{Conclusions}

The absence of commitment to the traditional Andean crops created a serious risk to the presence of quinoa cultivation in Peru in the second half of the 20th century. Abandonment of this crop was due both to the prioritization of other crops and the underutilization of land used for it. This trend was reversed in the last decade last century, bringing in a continuous period of land recovery and an expansion driven by national and international policies to promote Andean grains in general, and quinoa in particular.

The changes in the harvested areas do not show a repetitive cyclical behavior, but coinciding with a change in consumer perception of the product in recent years. The consolidation at current levels is foreseeable if the government acts with sustainability policies to avoid displacement by other crops.

In Peru, the grain has come to be cultivated in 19 of the country's 24 departments, clearly expanding the production base. In the last 30 years, the national area producing quinoa has tripled. The departments in which quinoa has traditionally been grown account for $97 \%$ of the total area, with Puno leading the way, although the highest growth rates have been in Arequipa and Ayacucho, while the departments where it has been recently introduced account for only $3 \%$.

The cartographic mapping of the departmental surface area in 2015 showed significant differences from that of 1992. This expansion indicates that there is a change in land use, displacing other species and recovery of quinoa-specific land.

The Sierra has a larger surface area for quinoa cultivation, but with a lesser possibility of expanding its growth. However, the Coast has a high growth potential due to geographical and technological conditions. Despite this, there has been a recovery of land use that guarantees the national grain supply and consolidating itself for the last six years.

\section{Acknowledgements}

To scholarship program PRONABEC from Perú for financial the doctorate study at UPV, Spain.

\section{Conflicts of Interest}

The authors declare no conflicts of interest regarding the publication of this paper. 


\section{References}

[1] Tapia, M. and Fries, A. (2007) Guia de campo de los cultivos andinos. Primera Edition, FAO y ANPE, Roma.

[2] Bazile, D., Bertero, D. and Nieto, C. (2014) Estado del arte de la quinua en el mundo en 2013. FAO (Santiago de Chile) y CIRAD, Montpellier.

[3] Jacobsen, S.-E. (2014) Adaptación y posibilidades para la quinua en las latitudes septentrionales de Europa. In: Bazile, D., Bertero, D. and Nieto, C., Eds., Estado del Arte de la Quinua en el Mundo en 2013, FAO y Montpellier-Francia, Santiago de Chile, 520-533.

[4] Gómez, L. and Aguilar, E. (2016) Guía de cultivo de la quinua. Segunda Edition, Universidad Nacional Agraria La Molina y FAO, Lima.

[5] Tapia, M., et al. (1979) La Quinua y la Kañiwa: Cultivos andinos. Instituto Intera-mericano de Ciencias Agrícolas (IICA) y el Centro Internacional de Investigaciones para el Desarrollo (CIID), Oficina Regional para América Latina, Bogotá.

[6] Winkel, T., et al. (2015) El presunto desastre ambiental y social de la quinua real: Desarmar los clichés para reforzar la ética. T' inkazos, 38, 127-142.

[7] Barrantes, C. (2015) El reto de la extensión agraria en el Perú: De la transferencia de tecnologías a un trabajo integrado sobre el territorio. Aplicación en la provincia de Aymaraes. Universidad Politécnica de Madrid, Madrid.

[8] Bedoya-Perales, N.S., Pumi, G., Mujica, A., Talamini, E. and Padula, A.D. (2018) Quinoa Expansion in Peru and Its Implications for Land Use Management. Sustainability (Switzerland), 10, 532. https://doi.org/10.3390/su10020532

[9] Mujica, A. and Jacobsen, S.-E. (2006) La quinua (Chenopodium quinoa Willd.) y sus parientes silvestres. Botánica Económica de los Andes Centrales, La Paz, 449-457.

[10] FAO (2011) La quinua: Cultivo milenario para contribuir a la seguridad alimentaria mundial. Oficina Regional para América Latina y el Caribe.

[11] Bioversity International, FAO, PROINPA, INIAF and FIDA (2013) Descriptores para quinua (Chenopodium quinoa Willd) y sus parientes silvestres. Roma-Italia, La Paz-Bolivia, Santiago-Chile.

[12] Popenoe, H., King, S., León, J., Sumar, K.L., Vietmeyer, N. and Dafforn, M. (1989) Lost Crops of the Incas: Little-Known Plants of the Andes with Promise for Worldwide Cultivation. The National Academies Press, Washington DC.

[13] Vargas, D.E., Boada, M., Araca, L., Vargas, W. and Vargas, R. (2015) Agrobiodiversidad y economía de la quinua (Chenopodium quinoa) en comunidades aymaras de la cuenca del Titicaca. IDESIA (Chile), 33, 81-87. https://doi.org/10.4067/S0718-34292015000400011

[14] Huillca, J. (2015) Quinua peruana: Análisis del sector y comparación internacional. Trabajo Final de Máster, Universidad Politécnica de Valencia, Valencia.

[15] Alandia, G., Rodriguez, J.P., Jacobsen, S.-E., Bazile, D. and Condori, B. (2020) Global Expansion of Quinoa and Challenges for the Andean Region. Global Food Security, 26, Article ID: 100429. https://doi.org/10.1016/j.gfs.2020.100429

[16] MINAGRI (2014) Quninua. Un futuro sembrado hace miles de años. Memoria del año internacional de la Quinua en el Perú. Primera Ed., Lima.

[17] MINAGRI (2017) Análisis económico de la producción nacional de la quinua. Lima.

[18] Ku, P. (2017) Perú como primer exportador de quinua a nivel mundial. Quipu-kamayoc, 25, 75-83. https://doi.org/10.15381/quipu.v25i47.13805 
[19] Bedoya-Perales, N.S., Pumi, G., Talamini, E. and Padula, A.D. (2018) The Quinoa Boom in Peru: Will Land Competition Threaten Sustainability in One of the Cradles of Agriculture? Land Use Policy, 79, 475-480. https://doi.org/10.1016/j.landusepol.2018.08.039

[20] MINAGRI (2019) Serie de estadísticas de producción agrícola (SEPA).

[21] Trade Map (2020) List of Importing Markets for a Product Exported by Peru. International Trade Center (ITC), Geneva. https://www.trademap.org/Index.aspx

[22] Schneider, M.M. (2014) Análisis de la cadena de valor de la quinua (Chenopodium quinoa willd.) en Bolivia. 147.

[23] Aroni, J. (2018) El sector de la quinua: Estudio comparativo entre Perú y Bolivia. Universidad de Buenos Aires.

[24] Schultz, T.W. (1967) Modernización de la agricultura. Madrid, Spain.

[25] Duárez, J.L. (2014) Los estudios sobre el neoliberalismo en el Perú. Entre legitimadores del discurso y críticos de la dominación. Revista de Sociología, 24, 281-305.

[26] MINAGRI (2012) Plan estratégico sectorial multianual 2012-2016. Lima. https://www.minagri.gob.pe/portal/download/pdf/conocenos/transparencia/planes estrategicos_regionales/pesem2012-2016.pdf

[27] Duárez, J.L. (2014) Los estudios sobre el neoliberalismo en el Perú. Revista de Sociología, 24, 281-305.

[28] Naciones Unidas (2013) Asamblea General: Sexagésimo séptimo periodo de sesiones (A/67/PV.64). Inauguración mundial del Año Internacional de la Quinua 2013. $64^{\circ}$ sesión. Documentos oficiales, Asamblea General de las Naciones Unidas, Nueva York. https://undocs.org/pdf?symbol=es/A/67/PV.64

[29] Jiménez, F. (2001) El modelo neoliberal peruano: Límites, consecuencias sociales y perspectivas. In: El ajuste estructural en América Latina. Costos sociales y alternativas, CLACSO, Buenos Aires, 145-169.

[30] Jacobsen, S., Mujica, A. and Ortiz, R. (2003) La importancia de los cultivos andinos. Fermentum. Revista Venezolana de Sociología y Antropología, 13, 14-24.

[31] Suárez, M.A. (2003) Caracterización del programa del vaso de leche. Lima.

[32] Rasmussen, S.K., et al. (2016) Worldwide Evaluations of Quinoa: Preliminary Results from Post International Year of Quinoa FAO Projects in Nine Countries. Frontiers in Plant Science, 1, 11. https://doi.org/10.3389/fpls.2016.00850

[33] Maletta, H. (2017) La pequeña agricultura familiar en el Perú. Una tipología microrregionalizada. FAO, Lima.

[34] Naciones Unidas (2011) Asamblea General: Sexagésimo sexto periodo de sesiones (A/RES/66/221). Año Internacional de la Quinua, 2013. $91^{\circ}$ sesión. Roma.

[35] Olarte-Calsina, S., Olarte-Daza, C.U. and Schultz, G. (2016) La quinua en el contexto de la estandarización. Agroalimentaria, 22, 1-28.

[36] Vargas-Huanca, D., Boada, M., Araca, L., Vargas, W. and Vargas, R. (2016) Sostenibilidad de modos ancestrales de producción agrícola en el Perú: Conservar o sustituir? Mundo Agrario, 17, 10.

[37] Huillca-Quispe, J. and Segura, B. (2019) Análisis de la expansión territorial del cultivo de quinua en la región andina de Sudamerica: Caso peruano. RIDAA, 73-75, 325-333.

[38] Altieri, M. and Nicholls, C. I. (2000) Agroecología. Teoría y práctica para una agricultura sustentable. Programa de las Naciones Unidas para el Medio Ambiente, Mexico.

[39] Angeon, V., Ozier-Lafontaine, H., Lesueur-Jannoyer, M. and Larade, A. (2014) Agroe- 
cology Theory, Controversy and Governance. In: Ozier Lafontaine, H. and Lesueur Jannoyer, M., Eds., Sustainable Agriculture Reviews, Springer, New York, 1-22. https://doi.org/10.1007/978-3-319-06016-3_1

[40] Sarandón, S.J., Zuluaga, M.S., Cieza, R., Gómez, C., Janjetic, L. and Negrete, E. (2006) Evaluación de la sustentabilidad de sistemas agrícolas de fincas en Misiones, Argentina, mediante el uso de indicadores. Agroecología, 1, 19-28.

[41] Sarandon, S.J. (2019) Potentialities, Challenges and Limitations of Agroecological Research as a New Paradigm in Agricultural Sciences. Revista de la Facultad de Ciencias Agrarias, 51, 383-394. 